\title{
Kelly's story: Transformative identity work in primary mathematics teacher education
}

\author{
Julie Alderton
}

Faculty of Education, University of Cambridge, Cambridge, UK

184 Hills Road, Cambridge, Cambridgeshire, CB2 8PJ

\section{Email: jha32@cam.ac.uk}

This article explores one female student teacher's experiences of learning to teach mathematics. Data included weekly emails and an interview through which she expressed her struggle to be recognised as mathematical and to be heard in pedagogical relationships within a subject that is discursively aligned with masculinity. Analysis drew on feminist post-structural understandings of discourse and power relations. I identify an array of discourses of gender, mathematics, ability, confidence and complex micro-relations of power which shaped her 'identity work' and examine how she was able to reposition herself positively as a teacher of mathematics, resisting dominant transmission-based approaches to teaching mathematics. While the course sought to challenge traditional mathematical pedagogies, gendered ways of being mathematical were not confronted. I argue that teacher educators need to pay attention to the way power circulates to marginalise and silence some students and to focus on transformation of their own identity work.

Keywords: feminist post-structuralism; gender; identity work; mathematics; primary teacher education; confidence 


\section{Introduction}

Kelly was a student teacher in one of my primary mathematics education groups during a ten month generalist postgraduate certificate in education (PGCE) programme leading to qualified teacher status at a university in London, England. In an initial tutorial Kelly professed a lack of confidence in her mathematical abilities. During the last 15 years as a primary mathematics teacher educator I have worked with many student teachers who have expressed feelings of ambivalence, fear, dislike or lack of confidence and have appeared not to participate fully during taught sessions. Such responses are welldocumented in the international literature (e.g. Bibby 2002; Hodgen and Askew 2007; Kaasila et al. 2008; Palmer 2009). Confidence in mathematics education is multifaceted. Burton (2004) maintains that labels of 'confident' or 'not confident' are too easily assigned. Llewellyn (2009) argues that there is an over-reliance upon its importance, whereas Graven (2004) observes that having the confidence to admit to what still needs to be learned is important for ongoing professional learning for mathematics teachers. In addition, it is well established that mathematics confidence in relation to gender is problematic (Mendick, Moreau, and Hollingworth 2008; Nunes et al. 2009; Walkerdine 1998).

In England, prevalent themes and difficulties with mathematics teaching are repeatedly reported in government publications, media stories and research findings. Hardy $(2009,189)$ claims that such accounts perform a 'faintly noticed essentialising shift' where primary teachers become pathologised as lacking in mathematical knowledge and ability, opening up forms of blame. Indeed, the first chapter in the core text for the mathematics education course is entitled 'Primary teachers' insecurity about mathematics' (Haylock, 2014: vii). It is within this cultural context that primary 
teachers 'train' and that the professional identities of 'trainee teachers' (as they are called in official discourses in England) are produced.

The wider study, upon which this paper is drawn, sought to explore the experiences of students in both locations of the university and partner school classrooms as they engaged in the processes of becoming primary teachers. I hoped that a better understanding of my students' perspectives on learning to teach mathematics might enable me to be more reflexive about my own practice. In order to understand how prospective teachers position themselves and are positioned, mathematics educators (Brown and McNamara 2011; Hossain, Mendick and Adler 2013; Neumayer-Depiper 2013; Nolan 2006) argue that it is vital to pay attention to identity formation in teacher education and problematise its facilitation. In-depth studies of small numbers of student teachers' responses to pedagogies in mathematics teacher education have, for example, explored categories of identity such as social class (Jackson and Povey 2015), 'race' (Hossain, Mendick and Adler 2013) and gender (Llewellyn 2009). As the study progressed I became particularly interested in the way my students became positioned as teachers and as mathematical in the intersection of a curriculum subject that is discursively aligned with masculinity and the culturally feminised profession of primary education. In addition, I also aimed to probe taken-for-granted assumptions and practices in teacher education. Together, these foci offer opportunities to seek to understand how patterns of inequality are reproduced in teacher education (Jackson and Povey 2015).

In the next section, I detail the theoretical perspective taken in relation to the key concepts of discourse, performativity and identity which are at the centre of this study. 


\section{The theoretical frame}

Adopting a post-structuralist perspective challenges assumptions that the development of mathematical knowledge, skills and competences resides within the individual. In this study I draw on Foucault's (1990) concept of discourse, which goes beyond spoken words in human conversation and on his notion of power, which locates the production of self-as-subject in discourse. Butler's (1999) theorisation of performativity is utilised to examine the formation of identities in discursive practices, as is Britzman's (1991) work on processes of negotiation and consent to identities in the specific context of teacher education.

Foucault (1990) reformulated power as not just constraining and repressing but also as positive and productive. In this analysis power is not the possession of individuals but operates through networks at both macro and micro-levels in social practices and relations and is in constant transformation. Walkerdine (1990) observes that different positions of power are inherent in discursive positioning. Some discourses 'come to dominate and bound legitimate knowledge' (Youdell 2006, 36), the idea of what is knowable as well as who can know. Discourses provide both teachers and their pupils with the identities through which they will be recognised and come to recognise themselves; therefore, identifying discourses of teacher education and mathematics is important.

Gillborn and Youdell (2000) argue that an understanding of 'ability' as fixed, is shared widely in British education and shapes policy and practice across the curriculum. This discourse is particularly dominant in relation to mathematics education in England (Marks 2013). Mendick (2006) observes that a discourse of mathematics as the ultimate form of rational thought, and thereby a proof of intelligence, frames teaching and constitutes learners' identities. She argues that a notion of 'specialness' in mathematics 
relies on the idea that not everyone can do it and that those who can, are born with this 'ability' (Mendick, Moreau and Epstein 2009, 72). Within this discourse categorising and grouping pupils by 'ability' can seem to be a reasonable way to teach mathematics. Brown and McNamara (2011) observe that school mathematics and teaching are shaped by social agendas and dominant discourses. Teaching strategies which prioritise teaching to national standardised tests become recognised as appropriate. This often involves the transmission of knowledge, a focus on rote learning and the modelling of mathematical procedures to be practiced by pupils. Such discursive practices can work to erase identities and agency for some learners. Youdell (2006), focusing on educational exclusion, demonstrates how intersecting discourses, such as 'race', gender, ability, sexuality, social class, sub-culture and religion constitute who comes to be recognised as a 'good' or 'bad' student.

Butler (1999) takes up Foucault's (1980) notion of the discursive production of the subject, introducing gender as a category of analysis in the development of her theory of performativity. Performativity proposes that genders are culturally acquired through repetition and 'performed' within particular contexts and social relationships: thus forms of identity are often internalised by the individual who takes them on. Such traits are fluid and can be taken up by men and women: as Llewelyn $(2009,422)$ maintains, 'we act within various fictions and anyone can perform as masculine or as feminine'. Conceiving categories of identity as unstable recognises the complexities of identity and power; however, it does not mean that all kinds of performances are available to all subjects. Mendick (2006), drawing on Butler's notion of performativity and of identity as being something we do rather than something we are, suggests that dominant discourses and cultural norms construct mathematics as objective not subjective and as rational not emotional. She argues that these oppositional discourses 
are gendered, inscribing mathematics as masculine, making it more difficult for girls and women to feel comfortable with and talented in mathematics. Therefore, 'doing mathematics is doing masculinity' (117). However, Pomeroy (2015) reminds us that in intersections with other structures, such as 'race' and class, not all masculinities align easily with doing mathematics. Identity work, as described by Mendick (2006), recognises the self as multiple, fractured and contradictory rather than certain and singular. This disrupts the binary of having or not having mathematical ability and presents possibilities of becoming mathematical in multiple ways in local and specific contexts and discursive practices.

\section{Research study}

I start by outlining key aspects of the methodological approach taken, then identify some tensions inherent in participant research and the dilemmas presented to researchers who attempt to engage in reflexive practice.

This paper focuses in depth on the experiences of one student teacher but is embedded in a larger study. The context of the study was a one year PGCE course for intending primary teachers based at a university in London and its partner schools. This short and intensive programme for graduates consists of 18 weeks on campus and 18 weeks in placement classrooms. Mathematics was one of eleven national curriculum subjects that made up the taught element of the PGCE course. The mathematics education course comprised 36 hours in total across 15 weeks. I was the mathematics education tutor for 48 students. I invited all to participate in the study and explained that my research aims were to explore their experiences, views, opinions and feelings on being a student on the mathematics course. I suggested that they communicate with me by email each week after the mathematics session. In total, 22 participated in the study. 
Of this larger sample, I selected eight to be interviewed. My sampling strategy was to represent a spectrum of relationships to mathematics. I chose four students whose emails included accounts of feelings of vulnerability in relation to mathematics and four who presented themselves as confident.

The findings arising from one of the eight interviewees, Kelly, are examined in detail in this paper because they provide an opportunity to shed light on some dominant discourses of the course, transitory positionings of power and the complexity of identity work in mathematics teacher education. What appears in my analysis of her accounts is inevitably the result of my own interpretations and prioritising. The evidence collected in relation to Kelly was carried out over 4 stages. Stage 1 comprised nine emails sent between January and the end of the mathematics course in April. These provided evidence of Kelly's feelings about how she experienced mathematics sessions, particularly in relation to collaboration with her peers. Stage 2 involved an initial analysis of this data in order to prepare an interview schedule which included the themes that Kelly had initiated. Stage 3 consisted of a 70 minute interview which was carried out in July just after she had successfully completed the PGCE course. Stage 4, which took place throughout the ten months of the course, encompassed my research diary in which I recorded reflections on and responses to interactions with students during both teaching and research activities.

In analysing the data, my focus is at the micro-level in a specific context to highlight micro-relations of power and raise questions about possibilities for change. The data were analysed thematically. I read and re-read emails, the interview transcript and diary entries, looking through theoretical lenses of discursive production, performativity and identity work with a particular focus on gendered performances and 
positioning, relationships with others, the learning context, and approaches to learning and teaching. In planning the research I did not initially foreground gender; gender emerged as an analytical lens as I engaged with both the literature and the data. I drew on inter-related processes to analyse discourse, as suggested by MacNaughton (1998). This involved identifying how categories, such as 'not being mathematical', are formed and expressed in language, how meanings are given to categories through social practices and identifying social power relations and effects of different discourses. If, for example, discourses of femininity and of mathematics construct the subject and produce contradictory identity work, then analysis can identify who benefits (and how) from the articulation and practice of a particular discourse. Povey, Angier and Clarke (2006) advise that, just as the curator takes time to hang a picture, researchers need to sit with their data and wonder how others will look at it. They recommend that 'we should consider the words that are not chosen from the transcript, the different plots and metaphors that might have been used, the suppression of other interpretations and perspectives' (462). This entails engaging with issues of power in the research encounter and how to make power relations between researcher and participant visible (Walkerdine, Lucey and Melody 2002).

\section{Ethics of Power}

Ethical and methodological difficulties are increased when the researcher is also responsible for teaching the participants. My positioning as researcher-practitioner afforded me an insider perspective which enabled more nuanced and complex understandings of the context. In addition, existing relationships with my students offered opportunities which I felt were reciprocal, building on mutual respect. My commitment to them was driven by these relationships, as were my sense of responsibility in the research encounter and the importance of taking their accounts 
seriously. However, Griffiths $(1998,41)$ warns of the 'risk of exploitation' when researchers, positioned within the community being researched, make use of the reciprocity and trust offered. Walkerdine, Lucey and Melody $(2002,194)$ contend that researchers are 'confronted with the inevitability of the place of power within the account and the way in which our own inscription as researchers produces a deeply uncomfortable gulf between ourselves and our participants'. I ensured that I was not responsible for visiting and assessing any of the interviewees during their school placements. However, I was in a position of authority as their mathematics tutor, responsible for assessing their engagement in the mathematics course through a subject knowledge audit and implementation of a personal action plan to further develop their knowledge. The nature of teacher education programmes can make student teachers feel under great scrutiny (Black-Hawkins and Amrhein 2014). I aimed to provide supportive opportunities for the students to reflect on their experiences and share their concerns and achievements. However, asymmetrical relationships of power clearly existed. This was visible in the data construction; students predominantly related positive feelings and experiences and any dissatisfaction with the course was often expressed indirectly or only after relaying positive comments and before expressing concern about offending me.

My recourse was to write a reflexive account by acknowledging the power relations between myself as tutor and my students and the vulnerability of their position. This included being mindful of how data construction, analysis and my subjectivities as researcher are interdependent and interconnected. My personal history and identity work as a woman who studied mathematics, became a primary school teacher and then a teacher educator shaped all aspects of the research. My own experiences of post compulsory mathematics education, including completing a mathematics degree, were 
marked by discursive alienation. I learned powerful lessons about what it is to be categorised and positioned as a woman in mathematics and felt empathy with students who recounted experiences of feeling marginalised. My subjectivities should be read into the account I offer.

Skeggs (2002) argues that the problems of power, privilege and perspective cannot be dissolved by claiming to offer a reflexive account. One difficulty lies in the notion that the reflexive researcher infers a knowing subject. Youdell (2006) challenges the implicit assumption of a reflexive researcher to assess rationally the actions, words, thoughts and meanings of both themself and the researched. Rejecting the neutral researcher and homogenous respondent does not resolve the dilemmas raised by 'constituted and located subjects doing research on or with other subjects who are also constituted and located' (61). Britzman (2000) identifies the messy problem of whether the participants, in her own study of student teachers, would see themselves as inventions of discourses and as fragmented subjectivities. Likewise, my analysis, construction and telling of her story constitutes Kelly as a subject and draws on theories that she may not have access to, so can be read as an imposition of epistemological authority. There is a danger that if theory is imposed upon participants, their accounts are pathologised and opportunities to destabilise unequal relationships are lost. It is important, therefore, that researchers acknowledge the positions of power they inhabit. Like Britzman (2000), I try to hold tightly to the ethic of not producing my participants either as heroes of resistance or as persons to blame. My concern must be one of questioning how the categories of blame and resistance become discursively produced and lived. I offer a research account that invites questions and re-analysis. 


\section{Kelly's story}

\section{Background and context of Kelly's prior experiences}

Kelly had attended a state secondary school and graduated in English Language and Linguistics at her local university, where the study took place. She then worked as a learning support assistant in both primary and secondary schools for five years. She came from a large family with six siblings and lived with her parents during the PGCE course. She identified as white British and was classified as a mature student at 29 years old. She held the minimum course entry requirement in mathematics i.e. a General Certificate of Secondary Education taken at age 16 (after which mathematics is no longer compulsory). This information is included to provide contextual data of her previous experiences of studying mathematics. It is not intended to imply any notion of her mathematical capabilities.

Kelly told me at the start of the course, 'I get really scared at first when I am doing maths'. She also shared that she was quite easily stressed. She only had memories of her secondary mathematics education and framed most of her teachers as prioritising speed and practice, which she found unproductive. However, she had positive recollections of one particularly inspiring teacher with a different approach, focusing on personal difficulties:

One of my teachers would ask me, 'What's wrong? Try and tell me where it's going wrong and then we can work on it'. She was more 'talk about maths' and what was wrong and where you're going wrong and the difficulties.

Kelly said that she would like to become more confident in her ability to break down mathematical ideas and be able to explain them to children. 


\section{Peer interactions and power relations in the mathematics course}

During the mathematics sessions Kelly tended not to volunteer answers or ask me questions and my perception was that she only she joined in whole group discussions in a very limited way. However, in contrast to my interactions with her during taught sessions, once I had issued the invitation, Kelly communicated with me regularly by email about her experiences of the taught course.

About half way through the year she wrote in an email:

I find maths quite tough. My mind switches off with all the technical jargon. Sometimes it feels as though we are talking about one thing and then someone takes the conversation in a different direction and a lot of the time over my head.

The lasting effects of past negative experiences of learning mathematics are well documented (Klein 2008). Kelly's positioning as non-mathematical seemed to be reinforced within the university-based mathematics sessions.

The emails that Kelly sent me were dominated by her experiences and frustrations of working with her peers during the taught sessions, for example:

I found it hard to learn anything, partly due to the people I was sitting with. It was difficult to let them know that I didn't understand even with their lengthy explanations. It was quite difficult to be able to input to the discussion particularly when there were a couple who were insistent on doing it their way.

During the interview, Kelly reiterated that she found contributing to discussions difficult.

In some of the groups I would sit in, you'd have a couple of people and they were very confident at maths and they would immediately say, 'Oh I know the answer' and would just blurt it all out. 
She went on to say that she usually let other people talk. She was constructed and constructed herself as powerless in the discourse of mathematics within relations of power with her peers. Some of her peers seemed to resist discourses of collaborative enquiry and a process-centred approach, promoted by the university course, implicitly drawing on culturally ascribed discourses of masculinity that emphasise competition, right answers and speed. They defended their positions to re-establish norms of doing mathematics through performances of mathematically knowledgeable and confident subjects.

Walkerdine $(1998,17-18)$ argues that 'truths' about women, such as that they are non-mathematical or 'quiet', need to be taken apart, in a 'process of disentangling' their 'forming and informing practices'. Kelly seemed to believe that at least parts of her performance were due to innate characteristics over which she had little control.

I'm quiet all the time and that's one of the things people pick up on is that I'm quiet in everything. Everything I do I'm quiet. So, I think that's just my personality.

However, Thompson and Bell (2011) contend that 'quiet' students actively comport themselves in 'quiet' ways because of how they read the landscapes within which they move. Kelly's performance (Butler 1999) as 'quiet' in sessions, a perceived feminised position (Burke 2015), located her in opposition to dominant discourses and constructions of the ideal student in higher education. Atkinson (2004) observes that a normalised view of the school teacher is that of a self-conscious, reflective and hardworking individual. To be active, independent and reflective foregrounds rational over emotional thoughts and has connotations with characteristics associated with masculinity (Burke 2015). The PGCE course strongly promoted the model of the proactive, conscientious student teacher who participated actively within all aspects of 
the course. Within authoritative discourses of dialogic education and collaborative learning, being a 'quiet' student is produced in binary opposition to the vocal, active student whose participation is seen as an integral part of the construction of knowledge. Foucault's (1979) concept of 'dividing practices' are instrumental in shaping the way that we think about students and how they come to think of themselves. Oppositional discourses, such as the active/passive subject, position students through deficit disorders which Burke (2015) argues are framed as neutral, decontextualised and disembodied traits producing differences that come to seem obvious and natural. Such categorisations, brought about through social practices including gendered (as well as classed and 'raced') constructions, can become defining characteristics that shape pedagogical relationships.

Kelly, having had significantly more classroom experience than most of her peers due to her previous job as a learning support assistant, was well placed to contribute to activities in sessions that integrated different types of knowledge about teaching mathematics. However, she felt that her contributions were not valued by her peers.

\footnotetext{
When you're slightly less confident you need a bit more time to think about it, to work it out, then it's a bit harder and in some of the discussions you do just let other people talk, not because you can't be bothered but just because sometimes you feel like your opinion is not valid as much as theirs because they've done their maths. They've got a lot of maths background or whatever.
}

Burke (2008) argues that 'other' bodies of knowledge that the student might bring to higher education contexts are often invalidated. Pedagogical content knowledge, such as how children learn mathematics, was promoted as a key priority of the course together with the development of knowledge of mathematics relevant to the primary curriculum. 
However, challenging the hierarchies of different kinds of knowledge and the nature of that knowledge, such as absolutist discourses of mathematics as a quick, efficient, rule based subject full of procedures to remember (Bibby 2002), is not easy within current discourses of education. Successive British governments have prioritised subject knowledge over pedagogical knowledge and blamed the ostensibly poor performance of English pupils on the mathematics subject knowledge and teaching of its teacher workforce (Brown and McNamara 2011). In recent years, the introduction of mathematics tests at interview for primary candidates, compulsory mathematical skills tests prior to starting courses and subject knowledge auditing during initial teacher education are ubiquitous. Well established processes of auditing and self-auditing mathematical knowledge for teaching effectively categorise students' performances and thereby students, like Kelly, into appropriate or inappropriate mathematicians.

Kelly's embodiment as a mathematics subject, who identified herself as lacking in confidence and knowledge, who participated in a limited way in group discussions and did not compete with her peers, could be seen as performing femininity (Butler 1999). Confidence can be defined as a function of the dynamics of the learning context and complex social and personal histories which, Burke (2008) argues, operate to privilege particular forms of knowledge and experience. The construction of mathematics as masculine, a subject in which the feminine is subtracted (Walkerdine 1998) works to 'other' some women within discourses of mathematics who, like Kelly, can be left with little space in which to manoeuvre.

\section{Power relations in school}

I now turn to how Kelly navigated her second teaching placement in school. Kelly started this placement with little experience of teaching mathematics to draw on 
from her first school placement. She had been paired with another student, Joseph, in the same class of 8 year olds. She explained:

I didn't get to teach it as much because it was sort of sharing the teaching and because Joseph was more confident in maths. I think the class teacher felt more confident to leave him to, you know, teach more of the maths whereas I taught more of the literacy.

I did not follow up with Kelly further the reasons for this division of curriculum teaching. I was surprised and disconcerted to find out about her limited participation in mathematics during her first placement as I had not been aware of it at the time. I suspected that the placement guidance had not been followed as closely as expected. She focused exclusively on her second placement in our discussion about her mathematics experiences in school.

Kelly described the pedagogy of her class teacher in her second placement as similar to the majority of her own secondary school teachers as drawing on procedural teaching approaches, prioritising speed, practice and testing.

I struggled a little bit because my class teacher was very different to me in her style and it was a very test orientated school. It was quite difficult because [the pupils] would say, 'I found it really hard', but not be able to explain why they found it hard. They were working really fast because they thought they had to get through everything.

She frequently referred to the requirements of the school curriculum and the difficulties she faced. Kelly constructed the class teacher as controlling details of space and time and herself as subject to the teacher's regulating gaze (Foucault 1979), positioning the teacher as constraining her pedagogical choices. However, Kelly's teacher was also located in discourses of schooling that constrained her practices and constructed her 
professional identity.

My class teacher didn't like me to stray too much from what they had already. They'd done all their plans and they basically copied them from the year before and didn't like me to change them much.

Perhaps Kelly did not 'stray' too much as a form of resistance to what she conceived of as more constructivist but unrealistic practicalities of the pedagogies that the university course promoted. Power differentials within my dual role of teacher-researcher make it difficult to know if she was positioning her relationship with me through criticising pedagogy of which she thought I would disapprove. Another possibility is that Kelly's acquiescence to her teacher was an act of survival, a strategic compliance. Britzman (1991) argues that student teachers are often forced to find the most direct route to survival in a system of rigid and high expectations with little margin for and willingness to forgive errors. However, as I will describe, Kelly did find strategies to resist procedural approaches in her teaching practices.

Significant shifts were evident in Kelly's developing sense of self as a prospective teacher of mathematics. Describing how she felt at the end of the course she said:

I am a lot more confident than when I started. I do feel a lot more confident in teaching it, a lot more competent when I'm teaching it. Before, I'd be teaching it but I didn't know what I was doing in my head. It would be like, 'I don't know how to explain it. I don't know how to do it. What if they ask me this question, what if they ask me that question?'

I read this response as Kelly developing an image of her future professional self, positioning herself as operating within officially sanctioned discourses of the 'confident' and 'competent' mathematics teacher. Hardy $(2009,192)$ notes that these 
two words go 'hand in hand' in the mathematics education arena, drawing attention to an almost unquestioned presumption of the conflation between confidence and competence as a common-sense truth.

Llewellyn (2009) argues that from a Foucauldian perspective, current regimes of truth create the fiction that to do mathematics is to do control. Kelly described how she responded to children's questions by the end of the placement:

Sometimes children just ask you the randomest questions and you can't just answer it there and then. I think it's sometimes good for them to see that you don't know all the answers all the time. I think it makes a good teaching point sometimes.

Kelly adopts a discourse aligned with masculinity, positioning herself as now fully in control of unexpected scenarios during lessons. However, she also subverts this discourse, constructing pedagogy in which processes are important and challenging the role of the teacher as that of an expert responsible for explaining mathematics clearly.

Brown and McNamara $(2011,96)$ offer caution about student teachers' 'happy resolutions' on course completion reported in their own study. They argue that the stories that pre-service students told left out issues that they preferred not to confront. Students spoke most frequently about empathy with children and classroom organisation. They understood difficulties with mathematics as a problem resulting from transmission oriented approaches to teaching. However, despite this approach being identified as the problem, the sophistication of their conception of teaching did not develop sufficiently for them to implement alternative styles: rather, they adopted a less severe version of transmission, 'delivering' mathematics but making it more enjoyable.

I argue that Brown and McNamara's (2011) analysis does not fully account for how Kelly constructed herself as a teacher of mathematics and the pedagogical 
strategies which she explored. As well as complying with her class teacher's pedagogic strategies, Kelly also found ways to implement alternative approaches aligned to her values and drew on different discourses of mathematics to subvert teaching-as-usual. She surprised her pupils by explicitly valuing mistakes and discussing pupils' thinking.

I think some of them thought I was joking at first because they were like, 'what you don't mind if we get them wrong?' and I'm like, 'no I'd rather you get them wrong, then we can talk about them and then we can find out why, what's wrong, what you're not particularly understanding'.

She disrupted practices that privilege modelling procedures, right answers and speed. She constructed mathematics as a subject that is best understood through discussion of learners' explanations and the importance of talk and self-reflection, wanting her pupils to 'be able to say to me what their problem was or what they found difficult about explaining it.' She seemed to be concerned with what Britzman $(1991,230)$ describes as 'more significant problems of how we come to know, how we learn, and how we are taught'. Kelly's divergence from established practice is, as Nolan (2006) observes, not an easy task for a novice teacher faced with the conservative power of school tradition and culture. In the next sections I consider what enabled Kelly to find spaces to manoeuvre to disrupt dominant pedagogies and authoritative discourses of mathematics in school.

\section{Finding spaces for transformation}

Kelly credited the university course with encouraging her to question and reflect on her previous practical classroom experience and to help her think about how children learn mathematics. 
You taught me to think more about how I was teaching, if that makes sense. You taught me to think about why I was doing things rather than just doing it.

Reflective practice as a means of self-development was central to the PGCE course. Kelly drew on this discourse, attributing informed reflection on past experiences of mathematics teaching and learning as enabling her to generate new understandings. Again, caution is needed here as the power positioning in our relationship could account for her praise for the taught course. In addition, as a teacher educator, this explanation is very appealing as a validation of the course.

Britzman (2000) argues that most people in teacher education are deeply invested in the idea that experience is telling and that one learns through rational reflection on experience. However, she contends that experience has no inherent essential meaning and identity does not follow unproblematically. Authoritative discourses of reflective practice presuppose that rational reflection brings about professional growth towards expertise but this assumes that the self is understood as coherent, fixed and rational, able to see the world as it really is. She suggests that processes of learning are more complex and fragile in relation to continuous constructions and shifts of discourse and identity. 'We bestow experience with meanings and these meanings are determined by habits, investments, fears, social conventions, dominant and sub-rosa discourses, and relations of power' (Britzman 1990, 80). I will argue that possibilities for Kelly to re-position herself as a teacher of mathematics were opened up through the negotiation of meanings and new subject positions supported by investments in emotional affinities with others and in the tensions between internally persuasive and authoritative discourses. 


\section{Emotional Affinities}

Zembylas (2003) identifies emotional affinities with others as empowering tools, describing them as connections or bonding based on coalitions and friendships. Kelly spoke about positive relationships with a number of individuals. These included her university placement supervisor, parents, children and a fellow student and described a series of incidents where she portrayed her practices and efforts as valued and successful. Butler (1997) argues the recognition by others of skills mastered is part of the process of subject formation.

Another relationship, with Catherine, a fellow student with whom she worked on mathematics outside the sessions, seemed to be particularly important:

Catherine helped me and she would explain things to me that I didn't quite get. And she'd say to me, 'Oh you got this one wrong, why did you get it wrong?' She would help explain it. And then through her explaining she would sort of treat me like the child and she would say, 'explain it back to me then, if you do understand it' and so, I think through that it has developed my subject knowledge.

Kelly's memories of a teacher at secondary school, who prioritised discussion about difficulties, paralleled the way she portrayed studying with Catherine. This relationship could be viewed as an unequal dynamic of a hierarchical teacher-pupil relationship with Catherine as the 'expert' and Kelly the 'student'. As she explained, 'she would sort of treat me like the child'. This kind of peer communication did not fit well with the proactive, independent learner authorised by the course and in my research diary I recorded my disappointment as it was not the type of peer interaction that I was hoping to foster. However, Kelly had positioned herself more strongly in relation to mathematics, taking up opportunities to talk and re-explain mathematical concepts. Whilst Kelly was listening to Catherine, she was also being 'heard' by her. She said, 'I 
don’t feel so stupid telling her I don’t understand'. Solomon (2012) argues that a discursive shift towards the valuing of collaboration and the recognition of contributions by all students have a particular impact on women but perhaps it is mutual acts of recognition within these relationships that are key. My initial misrecognition of Kelly as passive and lacking in confidence are drawn from gendered discourses and normalised views of the appropriate student.

\section{Internally persuasive discourse}

Drawing on Bakhtin, Britzman (1991) characterises one's own voice as an internally persuasive discourse. Internally persuasive discourse, as an example of a sub-rosa discourse, originates from autobiography and is located in family histories, students' school experiences as children, gender identities, faith traditions, cultural backgrounds and political commitments (Carson 2009). I argue that for Kelly the importance of learning mathematics through talk with trusted peers and teachers, by discussing and explaining strategies, understandings and mistakes, was an internally persuasive discourse.

It is possible that Kelly's apparent commitment to pedagogies of talk was a view that she felt I wanted to hear. Care needs to be taken, as how Kelly constructed herself in her interview and emails to me is bound up with and connected to the power relations within our relationship as student and tutor. However, there were other perspectives sanctioned by the course that Kelly did not seem to pay particular attention to. For example, other students commented on the way the course critiqued notions of ability in mathematics and school practices of grouping and setting (tracking). Kelly's placement school taught children in ability sets for mathematics but she did not comment on this practice, as she did on her class teacher's other pedagogies. 
Britzman $(1991,21)$ maintains that 'internally persuasive discourse provisions engagement with what we know and the struggle to extend, discard or keep it'. Spaces are opened up and identity work is fuelled when authoritative discourses come into contact with student teachers' internally persuasive discourse. She argues that internally persuasive discourse is the discourse of subversion and involves ongoing interaction with other discourses, while being tentative and subject to negotiation and shifting contexts. Learning to teach, therefore, becomes a struggle for personal voice as student teachers try to sort out where their own experiences and deeply held personal investments fit in relation to the authoritative discourses they encounter. Kelly's story includes incidents of being silenced and marginalised during university-based mathematics sessions and being regulated during her school placement. The mathematics course promoted conflicting discourses that challenged procedural approaches to teaching mathematics but at the same time did not trouble or make other discourses visible that continued to prioritise seemingly discursively masculine innate traits such as active participation and rational reflection or hierarchies of knowledge. I argue that Kelly's often painful experiences created dissonance, which sustained or compelled her to critically reflect on her struggles to strive to find some kind of resolution. Conflict triggered Kelly's interrogation and deep engagement in a dialogue about herself as a teacher, with how children learn mathematics, how she could teach differently and to construct herself as a confident mathematics teacher.

Britzman (1991) argues that learning to teach is always the process of becoming: a time of formation and transformation, of scrutiny into what one is doing and who one can become. Kelly's transformation can be recognised by shifts in her positioning in relation to mathematics and, in Butler's (1999) terms, a variation in the repetitive performances through which she is produced and recognised as a teacher of 
mathematics. Transformative identity work is something that is done, again and again. It is a performance embodied through relationships, clashes between internally persuasive discourse and other discourses, fears, oppression and challenges. It is contingent on specific contexts and social locations as well as wider discourses and gendered performances and is therefore precarious and constantly in motion.

\section{Conclusion}

Kelly's story demonstrates that it is possible, within the increasingly technical rational political enterprise of teacher education in England (Murray and Maguire 2007), for student teachers to find spaces to unsettle teaching-as-usual. She actively challenged dominant pedagogies of teaching mathematics in her placement school. However, I also identify gendered discourses at play in the way that she was marginalised as nonmathematical within the university course and constructed as passive, quiet and nonmathematical. A feminist post-structuralist perspective makes it possible to illustrate how learning to teach mathematics is not solely a cognitive and competence based endeavour but one deeply located in social relations and contexts. It enables attention to be drawn to how pedagogical relationships can be shaped by social identities such as class, 'race', age and gender (Jackson and Povey 2015) and how processes of misrecognition can operate to hide complex power relations.

Teacher educators need to reflexively scrutinise taken-for-granted assumptions about who can do mathematics, which kinds of performances of being mathematical and mathematical knowledge for teaching are valued and the consequences of positioning some students as lacking knowledge, confidence and ability. This involves finding ways of intervening in the binary discourses that frame our words, thoughts, feelings and actions about gender and mathematics (Mendick 2006) and other aspects of identity 
such as 'race' and social class. There are no simple solutions for teacher educators who might wish to support students' transformative identity work. I argue that teacher educators need to focus on transformation of our own identity work and the discursive landscapes in which we are produced. However, Neumayer-Depiper $(2013,14)$ argues that the 'development of mathematics teacher educator identities is just as complex as the work involved in teacher candidates' mathematics teacher identities.' We can start by being alert to how we negotiate, comply with, are positioned by and resist overlapping and contradictory discourses in the political climate in which teacher education is situated.

\section{References}

Atkinson, D. 2004. “Theorising How Student Teachers Form Their Identities in Initial Teacher Education.” British Educational Research Journal 30 (3): 379-394.

Bibby, T. 2002. "Shame: An Emotional Response to Doing Mathematics as an Adult and a Teacher.” British Educational Research Journal 28 (5): 705-721.

Black-Hawkins, K., and B. Amrhein. 2014. "Valuing Student Teachers' Perspectives: Researching Inclusively in Inclusive Education?” International Journal of Research \& Method in Education, 37 (4): 357-375.

Britzman, D. 1990. “Other Positions: A Rejoinder.” Curriculum Inquiry 20 (1): 79-81. Britzman, D. 1991. Practice Makes Practice: A Critical Study of Learning to Teach. Albany: State University of New York Press.

Britzman, D. 2000. “"The Question of Belief”: Writing Poststructural Ethnography.” In Working the Ruins: Feminist Poststructural Theory and Methods in Education, edited by E. St. Pierre and W. S. Pillow, 27-40. New York: Routledge.

Brown, T., and O. McNamara. 2011. Becoming a Mathematics Teacher: Identity and Identifications. Heidelberg: Springer Dordrecht.

Burke, P. J. 2008. "Writing, Power and Voice: Access to and Participation in Higher Education." Changing English 15 (2): 199-210. 
Burke, P. J. 2015. "Reimagining Higher Education Pedagogies: Gender, Emotion and Difference." Teaching in Higher Education 20 (4): 388-401.

Burton, L. 2004. “'Confidence is Everything' - Perspectives of Teachers and Students on Learning Mathematics." Journal of Mathematics Teacher Education 7 (4): 357-381.

Butler, J. 1997. The Psychic Life of Power: Theories in Subjection. Stanford: Stanford University Press.

Butler, J. 1999. Gender Trouble 10th Anniversary Edition. New York: Routledge.

Carson, T. 2009. "Teaching and Cultural Difference: Exploring the Potential for a Psychoanalytically Informed Action Research.” In The Sage Handbook of Educational Action Research, edited by S. E. Noffke and B. Somekh, 347-357. London: Sage.

Foucault, M. 1979. Discipline and Punish: The Birth of the Prison. New York: Vintage Books.

Foucault, M. 1980. Truth and Power. In Power/Knowledge: Selected Interviews and Other Writings 1972-1977, edited by C. Gordon, 109-133. New York: Pantheon Books.

Foucault, M. 1990. The History of Sexuality, Volume 1. An Introduction. Harmondsworth: Penguin

Gillborn, D., and D. Youdell. 2000. Rationing Education: Policy, Practice, Reform and Equity. Buckingham: Open University Press.

Griffiths, M. 1998. Educational Research for Social Justice: Getting off the Fence. Buckingham: Open University Press.

Graven, M. 2004. “Investigating Mathematics Teacher Learning within an In-service Community of Practice: The Centrality of Confidence." Educational Studies in Mathematics 57 (2): 177-211.

Hardy, T. 2009. "What Does a Discourse Oriented Examination Have to Offer Teacher Development?" In Mathematical Relationships in Education: Identities and Participation, edited by L. Black, H. Mendick, and Y. Solomon, 70-82.

Abingdon, OXON: Routledge.

Haylock, D. 2014. Mathematics Explained for Primary Teachers. 5th ed. London: Sage. 
Hodgen, J., and M. Askew. 2007. "Emotion, Identity and Teacher Learning: Becoming a Primary Mathematics Teacher." Oxford Review of Education 33 (4): 469-487. Hossain, S., H. Mendick, and J. Adler. 2013. "Troubling “Understanding Mathematics In-depth": Its Role in the Identity Work of Student-teachers in England." Educational Studies in Mathematics 84 (1): 35-48.

Jackson, C., and H. Povey. 2015. “"'Doing What Comes Naturally” in Mathematics Education? The Role of Social Class in Pre-service Teachers' Responses to Innovative Mathematics Pedagogies.” Mathematics Teacher Education and Development 17 (2): 199-212.

Kaasila, R., M. S. Hannula, A. Laine, and E. Pehkonen. 2008. "Socio-emotional Orientations and Teacher Change.” Educational Studies in Mathematics 67 (2): 111-123.

Klein, M. 2008. "Preservice Teachers and Numeracy Education: Can Poststructuralism Contribute?" In Navigating Currents and Charting Directions. Proceedings of the 31st Annual Conference of the Mathematics Education Research Group of Australasia, edited by M. Goos, R. Brown, and K. Makar, 317-322. Brisbane: MERGA.

Llewellyn, A. 2009. “'Gender Games': A Post-structural Exploration of the Prospective Teacher, Mathematics and Identity." Journal of Mathematics Teacher Education 12 (6): 411-426.

Marks, R. 2013. “"The Blue Table Means You Don't Have a Clue': The Persistence of Fixed-ability Thinking and Practices in Primary Mathematics in English Schools." FORUM 55 (1): 31-44.

MacNaughton, G. 1998. “Improving our Gender Equity 'Tools': A Case for Discourse Analysis." In Gender in Early Childhood Education, edited by N. Yelland, 149174. London: Routledge.

Mendick, H. 2006. Masculinities in Mathematics. Berkshire: Open University Press. Mendick, H., M.-P. Moreau, and S. Hollingworth. 2008. Mathematical Images and Gender Identities. Report for UK Resource Centre for Women in Science, Engineering and Technology (UKRC). London: UKRC and IPSE (Institute for Policy Studies in Education).

Mendick, H., M.-P. Moreau, and D. Epstein. 2009. “Special Cases: Neoliberalism, Choice and Mathematics." In Mathematical Relationships in Education: 
Identities and Participation, edited by L. Black, H. Mendick, and Y. Solomon, 70-82. Abingdon, OXON: Routledge.

Murray, J., and M. Maguire. 2007. "Changes and Continuities in Teacher Education: International Perspectives on a Gendered Field." Gender and Education 19 (3): 283-296.

Neumayer-Depiper, J. 2013. "Teacher Identity Work in Mathematics Education.” For the Learning of Mathematics 33 (1): 9-15.

Nolan, K. 2006. "Math Teaching Becomes you: The Challenges of Placing Identity Formation at the Centre of Mathematics Pre-service Teacher Education." In Proceedings of the 30th Annual Meeting of the Psychology of Mathematics Education (PME-30) Group, Prague, CZ, 16-21 July 2006.

Nunes, T., P. Bryant, K. Sylva, and R. Barros. 2009. Development of Maths Capabilities and Confidence in Primary School. Research Report DCSF-RR118. Palmer, A. 2009. “'I'm Not a "Maths-person”!' Reconstituting Mathematical Subjectivities in Aesthetic Teaching Practices." Gender and Education 21 (4): 387-404.

Pomeroy, D. 2015. “Physical' Masculinities and Mathematics.” Proceedings of the British Society for Research into Learning Mathematics 35 (2): 76-81.

Povey, K., C. Angier, and M. Clarke. 2006. "Storying Joanne, an Undergraduate Mathematician." Gender and Education 18 (5): 459-471.

Thompson. G., and J. Bell. 2011. "Mired in the Shadows: Quiet Students in Secondary Schools.” Discourse: Studies in the Cultural Politics of Education 32 (3): 399413.

Skeggs, B. 2002. Techniques for Telling the Reflexive Self. In Qualitative Research in Action, edited by T. May, 349-374. London: SAGE publications Limited.

Solomon, Y. 2012. "Finding a Voice? Narrating the Female Self in Mathematics." Educational Studies in Mathematics 80 (1): 171-183.

Walkerdine, V. 1990. Schoolgirl Fictions. London: Verso.

Walkerdine, V. 1998. Counting Girls Out. London: Verso.

Walkerdine, V., H. Lucey, and J. Melody. 2002. Subjectivity and Qualitative Method. In Qualitative Research in Action, edited by T. May, 179-198. London: SAGE publications Limited. 
Youdell, D. 2006. Impossible Bodies, Impossible Selves: Exclusions and Student Subjectivities. Dordrecht: Springer.

Zembylas, M. 2003. "Emotions and Teacher Identity: A Poststructural Perspective." Teachers and Teaching: theory and practice 9 (3): 213-238. 